\title{
Awareness of Laser Dentistry Among Undergraduate Dental Students
}

\author{
Vasishta. P. A' ${ }^{1}$ Dhanaraj Ganapathy ${ }^{2}$ and L. Keerthi Sasanka ${ }^{3}$ \\ ${ }^{1}$ Undergraduate student Saveetha Dental College and Hospitals Saveetha Institute of Medical \\ and Technical Science (SIMATS) Saveetha University, Chennai-77,Tamil Nadu, India \\ ${ }^{2}$ Professor and Head, Department of Prosthodontics Saveetha Dental College and Hospitals Saveetha Institute \\ of Medical and Technical Science (SIMATS) Saveetha University, Chennai-77,Tamil Nadu, India \\ ${ }^{3}$ Senior Lecturer, Department of Prosthodontics Saveetha Dental College and Hospitals Saveetha Institute \\ of Medical and Technical Science (SIMATS) Saveetha University, Chennai-77,Tamil Nadu, India
}

\section{ABSTRACT}

Lasers can make dental treatments more efficient, more cost-effective and more convenient. Laser dentistry has been approved by the Food and Drug Administration (FDA), as a treatment option for several dental conditions. The word LASER stands for "light amplification by stimulated radiation emission." The instrument produces light energy in a very small, centered beam. This laser light causes a reaction when it hits tissue which allows the tissue to be removed or formed. Lasers in the field of dentistry have wide scope in treating certain dental conditions, but majority of the laser treatments are used in aesthetic procedures. The aim of the study is awareness of laser dentistry among undergraduate dental students.A comprehensive cross-sectional study was conducted among 104 undergraduate dental students. A self-administered, close-ended questionnaire has been created and distributed among college students to learn about their knowledge about Laser Dentistry. 50\% of the undergraduate students were aware about Laser dentistry. From the above results the following conclusion can be drawn that most of the students have a basic idea about what a laser is and its uses in dentistry but they are not aware of types of lasers.

\section{KEY WORDS: LIGHT AMPLIFYING DEVICE; HARD TISSUE; SOFT TISSUE; DENTISTRY; WAVELENGTH.}

\section{INTRODUCTION}

The word LASER stands for "Light Amplification By Stimulated Radiation Emission." The instrument produces light energy in a very small, centered beam. This laser light causes a reaction when it hits tissue which allows the tissue to be removed or formed(Graeber, 2006). The first laser was invented in 1964, where it eventually

\section{ARTICLE INFORMATION}

*Corresponding Author: keerthis.sdc@saveetha.com Received 1st Aug 2020 Accepted after revision 21st Sep 2020 Print ISSN: 0974-6455 Online ISSN: 2321-4007 CODEN: BBRCBA

Thomson Reuters ISI Web of Science Clarivate Analytics USA and Crossref Indexed Journal

\section{Clarivate
Analytics}

NAAS Journal Score 2020 (4.31) SJIF: 2020 (7.728)

A Society of Science and Nature Publication,

Bhopal India 2020. All rights reserved.

Online Contents Available at: http//www.bbrc.in/

Doi: http://dx.doi.org/10.21786/bbrc/13.8/160 had many modifications with a desire to implement in various fields like Defence, Scientific Research, Industries, Civil Constructions and Medical purposes(Dostálová and Jelínková, 2013). From the last three decades there was an evolution of lasers in the field of medicine within the disciplines of Ophthalmology, Dermatology and General surgery. In 1989 the lasers were introduced in dental treatments and it became commercially used for procedures in clinical dental practice(Pradhan, 2017).

History of lasers in dentistry: Lasers were first introduced by Prokhoruv, Maimen \&t Towens with their first innovation of gas laser in the year 1961. Now lasers are widely used in dentistry. Laser was first brought into dental practice in 1989 Drs. William and Terry Myers and they modified an ophthalmic Nd:Yag (Yttrium aluminum garnet) laser for dental use(Shih, 2012; Mahajan, Srivastava and Coluzzi, 2017). In 1960, laser was first introduced in dentistry,

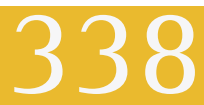


Later Gelskey S C introduced Nd; Yag laser which can be used for dentine hypersensitivity and lasers for cavity preparation was introduced in 1993. C02 and argon lasers were introduced in the year 1994. Laser weider was introduced in 1996. Yttrium aluminum perovskite (Nd: YAP) was introduced in 1997 and finally in the year 1998, Er : YAG hard tissue or osteotomy laser was introduced(Miserendino and Pick, 1995).

Lasers in the field of dentistry have wide scope in treating certain dental conditions, but the majority of the laser treatments are used in aesthetic procedures(Rechmann, Goldin and Hennig, 1998). Laser dentistry potentially offers a more comfortable treatment option compared to drills and other non-laser tools for a number of dental procedures involving hard or soft tissue. Laser dentistry is used in a number of treatments, including: dentinal hypersensitivity, treatment of tooth decay, treating periodontal diseases, teeth whitening etc, advanced procedures involving surgical implantology, soft tissue contouring in fixed dental treatments, hard tissue treatment in restorative dentistry and soft tissue contouring/incisions in Oral surgery.

Lasers can make these dental treatments more efficient, convenient and cost-effective. The use of Lasers dentistry has also been approved by the Food and Drug Administration (FDA), as a treatment option for several dental conditions(Yamamoto, Atsumi and Kusakari, 1989). It is worth noting that the American Dental Association (ADA) has yet to do so at this time, although they are hopeful about the field's potential. The two principal types of lasers available for the procedures in dentistry are hard tissue and soft tissue lasers. Hard tissue is the teeth, and soft tissue is the gums(Mahajan, Srivastava and Coluzzi, 2017).

Laser effects on tissue: Light focussed by lasers on tissue might get reflected, absorbed, scattered throughout the tissue or transmitted into the tissue. Reflected light usually bounces off the tissue surface and is directed outwards. Scattered light bounces within the tissue(Zein, 2017). The absorption property of lasers is responsible for thermal effects within the tissue and transmission of light irradiates the surrounding tissue. So the primary beneficial goal of lasers is absorption of light. There are two photo biologic effects possible while using dental lasers, they are photothermal and photochemical(Ramos et al., 2015).

1. Photochemical effects that lasers produce to stimulate chemical reactions, such as composite resin healing. These can also induce a breakdown in chemical bonds, such as during the photodynamic therapy phase.

2. Photo ablation-When a laser is absorbed it raises the temperature and produces photochemical effects depending on the tissue's water content. When the temperature is ex $100^{\circ}$ (Freitas et al., 2015).

Fluorescence of the tissue-used as a diagnostic method for the detection of light reactive substance in tissue. So, e.g. Diagnodent 4 for detection of caries. Vaporization \& Carbonization-Proteins begin to denature at temperatures below $100^{\circ} \mathrm{C}$ but above nearly $60^{\circ} \mathrm{C}$, without vaporizing the underlying tissue. On the other hand, the tissue is then burnt at temperatures above $200{ }^{\circ} \mathrm{C}$, resulting in carbonisation(Ramalho et al., 2015).

\section{Classification}

Lasers are generally classified into 4 types based on their wavelength and power output.

Class 1: Viewing with the nakied eye. Examples include $\mathrm{CD}$ players and caries detection.

Class 2: This can be viewed using both naked eye and magnification. For example laser pointers.

Class 3: These are laser measuring devices. Example: soft medical lasers.

Class 4: These are high powered industrial, scientific, military, surgical lasers. All surgical lasers used in dentistry and oral and maxillofacial surgery lasers have been included(Jablonski-Momeni et al., 2019).

\begin{tabular}{|c|c|c|}
\hline S.No & LASER TYPE & APPLICATION \\
\hline 1. & Carbon dioxide & $\begin{array}{c}\text { Incision of soft } \\
\text { tissue and de- } \\
\text { epithelialization of } \\
\text { gingival during } \\
\text { periodontal regenerative } \\
\text { procedures. }\end{array}$ \\
\hline 2. & $\begin{array}{l}\text { Neodymium: Yttrium } \\
\text { aluminium garnet }\end{array}$ & $\begin{array}{l}\text { Incipient caries } \\
\text { removal and soft tissue } \\
\text { incision and ablation. }\end{array}$ \\
\hline 3. & $\begin{array}{l}\text { Erbium: Yttrium- } \\
\text { aluminium garnet }\end{array}$ & $\begin{array}{c}\text { Caries removal, cavity } \\
\text { preparation, root canal } \\
\text { preparation and U.S. FDA } \\
\text { clearance for use of melting } \\
\text { or alteration of the calcium. }\end{array}$ \\
\hline 4. & $\begin{array}{l}\text { Erbium, Chromium: } \\
\text { Yttrium- selenium- } \\
\text { Gallium Garnet }\end{array}$ & $\begin{array}{l}\text { Enamel etching, caries } \\
\text { removal, cavity preparation, } \\
\text { cutting bone in vitro } \\
\text { without burning, and } \\
\text { melting or alteration of } \\
\text { calcium: phosphorus ratio } \\
\text { in root canal preparation. }\end{array}$ \\
\hline 5. & Argon & $\begin{array}{l}\text { Curing resins, soft tissue } \\
\text { incision and ablation } \\
\text { and also used in bleaching. }\end{array}$ \\
\hline 6. & $\begin{array}{l}\text { Holmium: Yttrium } \\
\text { Aluminium- Garnet }\end{array}$ & $\begin{array}{c}\text { Soft tissue incision and } \\
\text { ablation }\end{array}$ \\
\hline 7. & $\begin{array}{l}\text { Gallium Arsenide } \\
\text { (or diode) }\end{array}$ & $\begin{array}{l}\text { Soft tissue incision } \\
\text { and ablation }\end{array}$ \\
\hline
\end{tabular}


Now coming to the classification based on content of active media, wavelength spectrum, energy levels, and operation. They can be solid media like Nd: YAG (1064nm, 1350nm ), Ruby lasers (94nm), holmium -YAG laser (2100nm), Erbium laser (2960nm), Krypton Laser $(476 \mathrm{~nm}, 521 \mathrm{~nm}, 468 \mathrm{~nm}, 647 \mathrm{~nm})$ and also with gas media like Carbon Dioxide (10,600nm), Argon laser (488514nm), Helium Neon (633nm), Gold vapour (628nm), Excimer lasers are further classified into argon fluoride (193nm), krypton fluoride (248nm), Krypton chloride $(222 \mathrm{~nm})$, xenon chloride (308nm) and xenon fluoride $(351 \mathrm{~nm})$ and there are also liquid media lasers like Dye Laser fluorescent organic dyes(Olivi and Olivi, 2015).

Hard tissue Lasers: Common procedures relating to hard tissue include: Cavity detection; Lasers can detect cavities early by finding evidence of tooth decay. Tooth preparations and Restorations; Local anesthesia and traditional drills are often not needed with laser treatments. Bacteria present in the oral cavity can be killed with the help of lasers, which maintains tooth health for longtime. To treat sensitivity; Teeth sensitive to hot and cold can be treated with dental lasers which seal tubules on the root of the tooth. Dental practitioners either use lasers for hard tissue or for soft tissue, depending on the procedure. Lasers with hard tissue will cut through the surface of the dents. The wavelengths are absorbed by water and a particular mineral that is embedded in teeth.These lasers are most commonly used for preparing or shaping composite bonding teeth, repairing worn-out dental fillings, and removing a certain tooth structure(Miserendino and Pick, 1995).

Soft tissue applications: Wound healing, Post herpetic neuralgia and aphthous ulcer, Photoactivated dye disinfection using lasers, Photodynamic therapy for malignancies(PDT), Aesthetic gingival re contouring and crown lengthening, Exposure of unerupted and partially erupted teeth, Removal of inflamed, hypertrophic tissue, and miscellaneous tissue removalIsolated areas of transient tissues, Frenectomies(Sulieman, 2005; Vescovi et al., 2010; Heinrich et al., 2011).

Other laser procedures include: Tissue viewing. Optical consistency tomography helps a doctor to see a tooth or gum tissue securely inside it. Removal of benign tumours. A pain-and suture-free method allows lasers to extract *tumors from the tongue, gums, and sides of the lips and cheeks $(8,9)$. Treating apnea to obstructive sleep. Lasers can reshape the throat and relieve related respiratory problems while sleeping.

Benefits of using laser dentistry over conventional methods: The need for sutures with soft tissue lasers is theoretically diminishing. Bleeding in treated soft tissues is minimized, as the laser promotes blood clotting. Anesthesia is unnecessary, with some procedures. There's less risk of bacterial infections because the laser sterilizes the region. Wounds can heal more easily, and tissue can regenerate. The procedures will result in less damage to surrounding tissues(Vescovi et al., 2010). Soft tissue lasers can be absorbed via hemoglobin and water. Hemoglobin is a protein which can be found in red blood cells. These lasers are used to treat periodontitis including bacteria killing and tissue regrowth activation.Lasers of soft tissue surround the nerve endings and blood vessels when penetrating the tissue. For this reason, after laser treatment, many feel virtually no pain. The lasers also facilitate faster tissue healing(Vescovi et al., 2010).

Laser dentistry disadvantages: Lasers can not be used on teeth which already have certain types of filling such as amalgam. Sometimes hard lasers can injure pulp on the tooth. Now, some laser procedures need anesthesia. Laser dentistry risks are comparatively small. Finding a suitable dental professional is crucial, because using the wrong wavelength or power level might harm the tissue(Aronoff, 1982).

Furthermore, some services fear that advertisers are going beyond what people actually need to use laser treatment. To find a qualified laser treatment dentist, search for a professional who has taken educational courses and received the proper training. Popular sources of education are the dental schools and associations, as well as the Laser Dentistry Academy (ALD). You can also seek recommendations from your insurance provider and ask friends and family who have had positive experiences with laser dentistry(Khalkhal et al., 2020). Our department has previously published articles on prosthetic dentistry Ganapathy, Kannan and Venugopalan, 2017; Jain, 2017a, 2017b; Ranganathan, Ganapathy and Jain, 2017; Ariga et al., 2018; Deogade, Gupta and Ariga, 2018; Anbu et al., 2019; Ashok and Ganapathy, 2019; Duraisamy et al., 2019; Varghese, Ramesh and Veeraiyan, 2019), this vast research experience has inspired us to research about awareness of laser dentistry among undergraduate dental students.

Figure 1: The above given figure represents the Awareness about lasers used in dentistry among undergraduate students. Blue colour indicates 'yes' and red colour is 'no'. $73.08 \%$ of the survey population is aware about lasers used in dentistry while the other $26.92 \%$ are unaware.

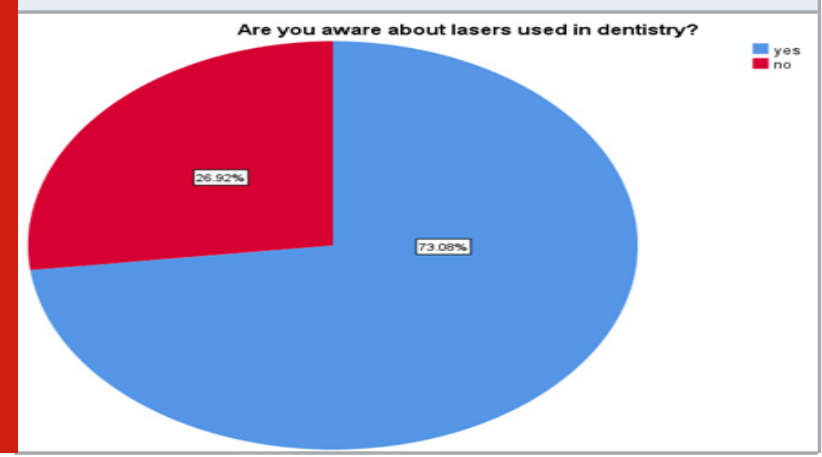

MATERIAL AND METHODS

A comprehensive cross-sectional study was conducted among 104 undergraduate dental students. A selfadministered, close-ended questionnaire has been created and distributed among college students to learn 
about their knowledge about Laser Dentistry. Language was restricted to english.

Figure 2: The above given figure represents the association between gender with the awareness about lasers used in dentistry among undergraduate students. Blue colour indicates 'yes' and red colour is 'no'. X-axis represents gender and $\mathrm{Y}$-axis represents the number of participants. $49 \%$ of the male population is aware about lasers while only $27 \%$ of the female population is aware about lasers used in dentistry. Chi-square value $=1.030, \mathrm{P}$ value $=$ 0.310 , (>0.05 ) Hence, statistically not significant. Although statistically not significant it is implied that the majority of males (49\%) are more aware about lasers in dentistry rather than females.

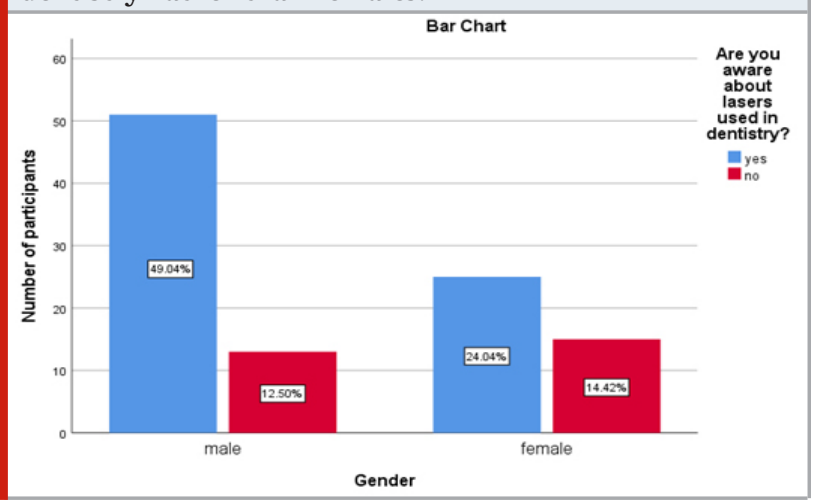

Figure 3: The above given figure represents the number of lasers available in dentistry. blue is one, red is two and green is three. $58.65 \%$ of the population are aware that two types of lasers are available.

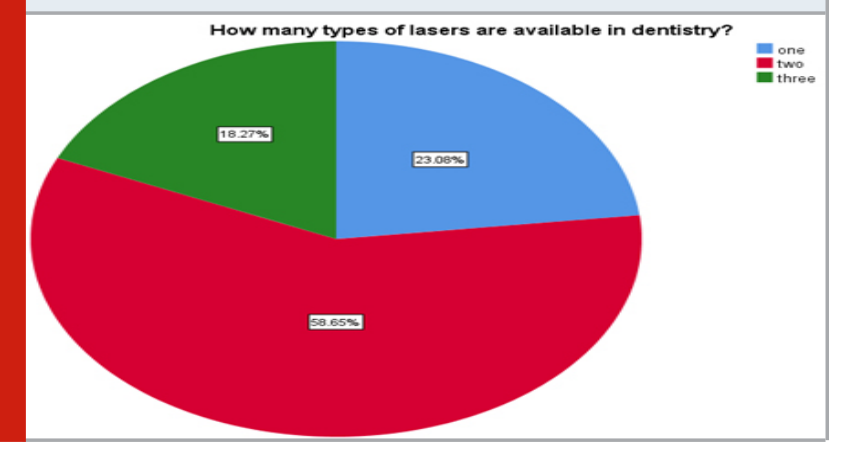

RESULTS AND DISCUSSION

From the above survey we can understand the knowledge about laser technology in dentistry among college students. Figure: 1: represents the Awareness about lasers used in dentistry among undergraduate students. 73.08\% of the survey population is aware about lasers used in dentistry while the other $26.92 \%$ is unaware. Figure: 2: represents the Awareness about lasers used in dentistry among undergraduate students among different genders. $49 \%$ of the male population is aware about lasers while only $27 \%$ of the female population is aware about lasers used in dentistry. Figure:3: represents awareness about how many types of lasers available in dentistry. 23.08\% of the college students have told that it is one, 58.65\% have told it is as two and 18.27\% have told it as three. Figure: 4 : represents awareness about how many types of lasers available in dentistry among different genders. $22 \%$ of males and 2\% of females tell it as one, 36\% of the males and $25 \%$ of the females tell as two and $12 \%$ of males and 7\% of females tell as three.

Figure 4: The above bar chart represents the number of lasers available in dentistry. blue is one, red is two and green is three. $\mathrm{X}$-axis represents gender and $\mathrm{Y}$-axis represents the number of participants. $30.77 \%$ of the male population say it as two and also $27.88 \%$ of the female population say it as two. Chi-square value $=8.526, \mathrm{P}$ value $=0.014,(<0.05)$ hence, statistically significant. Majority of males $30.77 \%$ are aware about types of lasers available in dentistry rather than females.

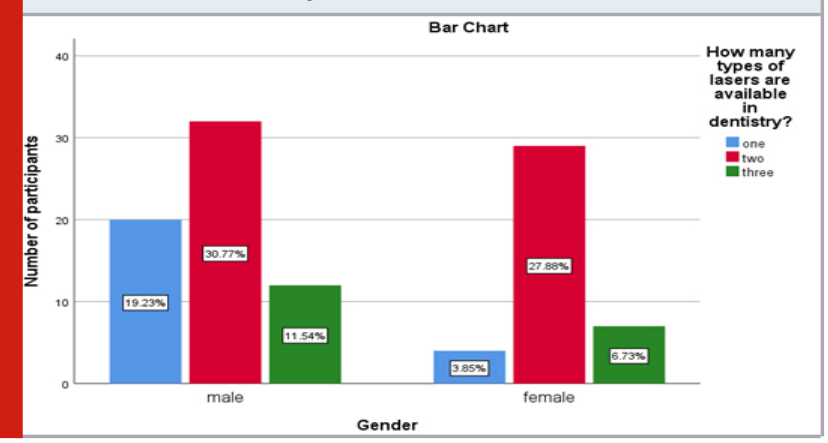

Figure 5: The above given figure represents the most common classification of lasers in dentistry. Blue is hard tissue lasers, red is soft tissue lasers and green is both. $71.15 \%$ of the population say it as both hard and soft tissue lasers.

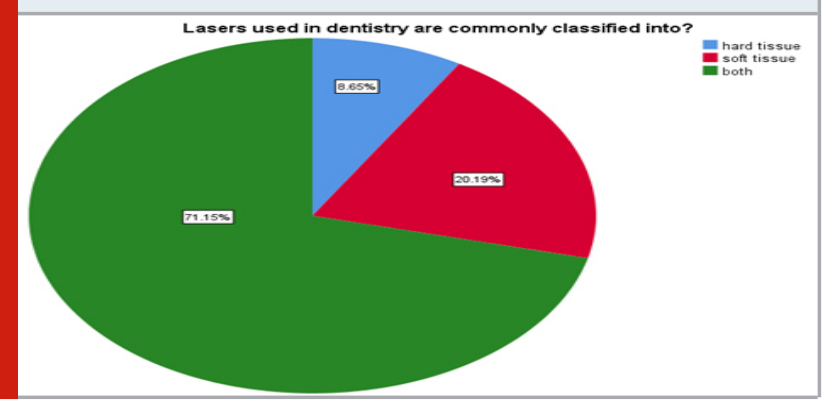

Figure: 5: Lasers used in dentistry have been classified into soft tissue, hard tissue or both but $20.19 \%$ students have told it as soft tissue, $8.65 \%$ have told it as hard tissue 71.15\% told it as both hard tissue and soft tissue. Figure: 6: represents the types of lasers used in dentistry among different genders. $48 \%$ of the males and $26 \%$ of the females tell it as both. Figure: 7: 79.81\% students think that lasers diverge and only 20.19\% say that lasers don't diverge. Figure: 8: represents the divergence property of lasers. $60 \%$ of the males and 23\% of the females have told yes lasers diverge. Figure: 9: Awareness about most commonly used laser over hard tissue. $32.69 \%$ of students say that CO2 is widely used in hard tissue, $36.54 \%$ say it as Argon, $13.46 \%$ say it as erbium and only $17.31 \%$ 
is aware that HeNe is the most commonly used laser over hard tissues. Figure: 10: Most commonly used laser over hard tissue among different genders. 11\% of the males and 7\% of females are aware that HeNe is most commonly used over soft tissues.

Figure 6: The above bar chart represents association between gender and the most common classification of lasers in dentistry. Blue is hard tissue lasers, red is soft tissue lasers and green is both. $\mathrm{X}$-axis represents gender and $\mathrm{Y}$-axis represents the number of participants. 36.54\% of the male population is aware that both soft and hard tissue lasers come under commonly used classification whereas only $34.62 \%$ of the female population is aware. Chi-square value $=0.955, \mathrm{P}$ value $=0.620,(>0.05)$ hence, statistically not significant. Although statistically not significant it is implied that, majority of males $36.54 \%$ are aware about the types of lasers available rather than females.

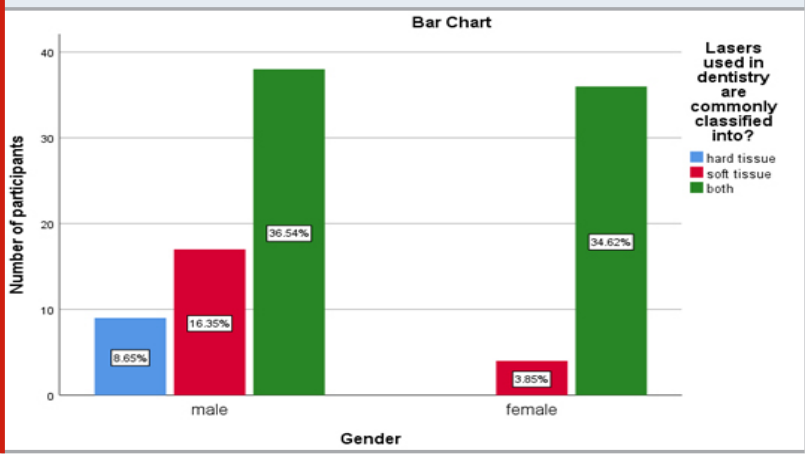

Figure 7: The above given figure represents the Awareness about lasers used in dentistry among undergraduate students. Blue colour indicates 'yes' and red colour is 'no'. Only $79.81 \%$ of the population is aware that lasers diverge.

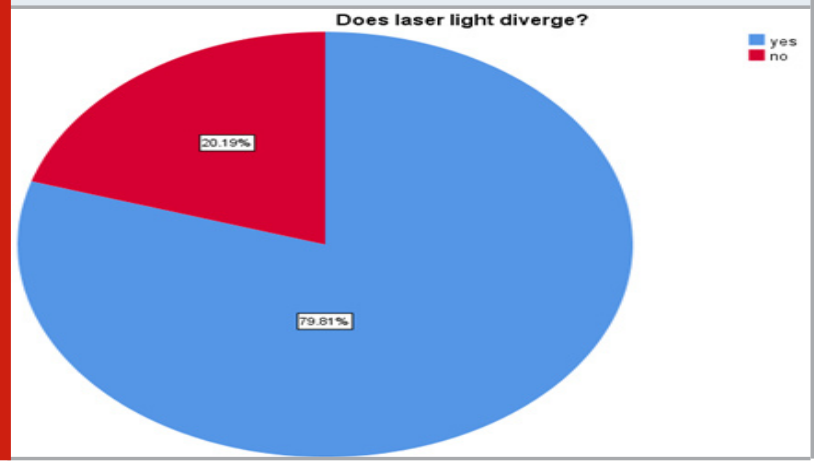

Figure: 11: Awareness about Most commonly used lasers over soft tissue. Only $27.88 \%$ of students are aware that CO2 is widely used in soft tissue, $27.88 \%$ say it as Argon, 24.04\% say it as erbium and $20.19 \%$ say it as HeNe. Figure: 12: Awareness of the most commonly used laser over soft tissue. Only 19\% of the males and 10\% of the females tell it as CO2. Figure: 13: represents whether hard tissues lasers can be used over soft tissues. $59.62 \%$ say it as yes, $22.12 \%$ say it as no, and $18.27 \%$ don't have any idea. Figure: 14: represents knowledge about usage of hard tissue lasers over soft tissue among different genders. $44 \%$ of the males and $18 \%$ of the females say that yes hard tissue lasers can be used over soft tissues.

Figure 8: The above given figure represents the Awareness about lasers used in dentistry among undergraduate students. Blue colour indicates 'yes' and red colour is 'no'. X-axis represents gender and Y-axis represents the number of participants. $48.08 \%$ of the male population is aware that lasers diverge and whereas $31.73 \%$ of the female is aware about this. Chi-square value $=4.635$, $\mathrm{P}$ value $=0.031,(<0.05)$ hence, statistically significant . Majority of males $48.08 \% \%$ are aware about the types of lasers available rather than females.

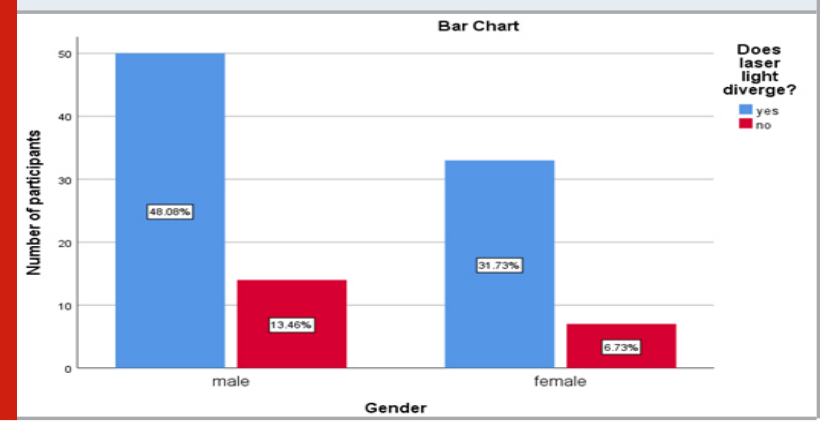

Figure 9: The above given figure represents the lasers used on hard tissue. Blue is $\mathrm{CO} 2$, red is argon, green is erbium and orange is HeNe. Only $32.69 \%$ is aware that Erbium is the most commonly used laser in hard tissues.

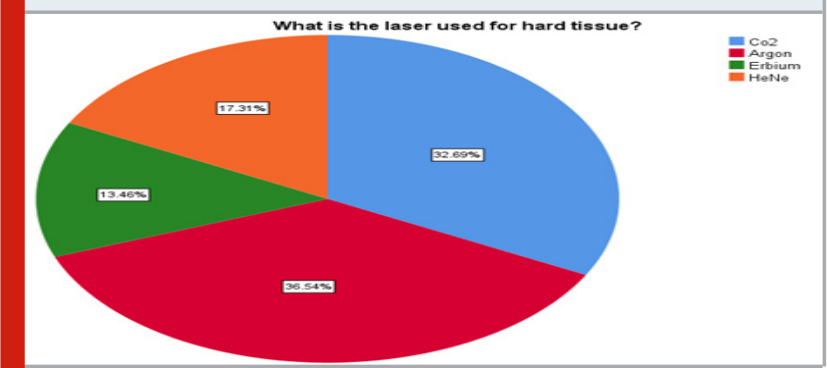

Figure 10: The above given figure represents the lasers used on hard tissue. Blue is $\mathrm{CO} 2$, red is argon, green is erbium and orange is HeNe. $\mathrm{X}$-axis represents gender and $\mathrm{Y}$-axis represents the number of participants. $7.69 \%$ of the male population say it as HeNe and even $5.77 \%$ of female population say it as Erbium . Chi-square value $=0.616, \mathrm{P}$ value $=0.893,(>0.05)$ hence, statistically not significant. Although statistically not significant it is implied that, majority of males $7.69 \%$ are aware about the type of lasers used in hard tissues.

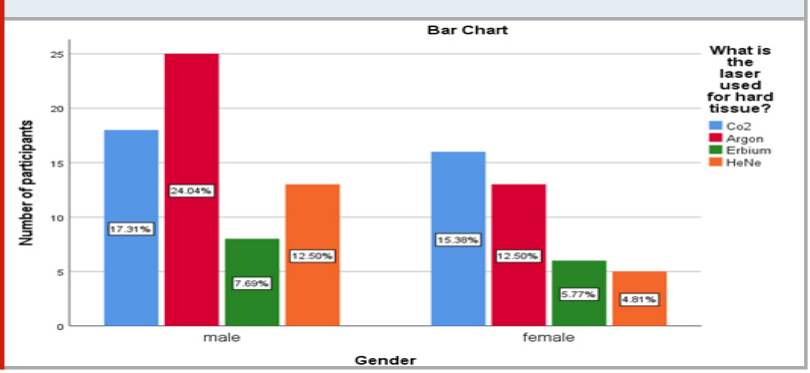


Figure 11: The above given figure represents the lasers used on soft tissue. Blue is $\mathrm{CO2}$, red is argon, green is erbium and orange is HeNe. Only $27.88 \%$ of the survey population is aware that $\mathrm{CO} 2$ lasers are most widely used over soft tissues.

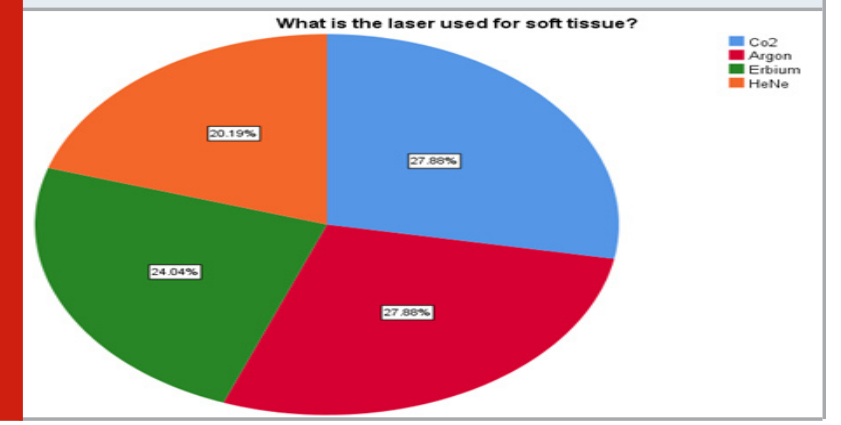

Figure 12: The above given figure represents the lasers used on soft tissue. Blue is $\mathrm{CO2}$, red is argon, green is erbium and orange is HeNe. $\mathrm{X}$-axis represents gender and $\mathrm{Y}$-axis represents the number of participants. $18.27 \%$ of the male population and $9.62 \%$ of female population say it as $\mathrm{CO}$. Chi-square value $=0.088, \mathrm{P}$ value $=0.993,(>0.05)$ hence, statistically not significant. Although statistically not significant it is implied that, majority of males $18.27 \%$ are aware about the type of laser used for soft tissues.

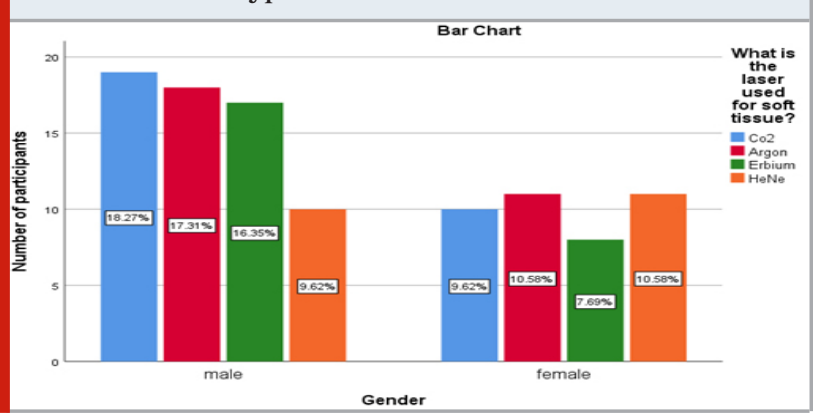

\section{CONCLUSION}

While lasers can not replace all traditional dentistry procedures, their use allows some procedures to be done differently from the standard method and their advancement in the field of dentistry continues to expand further, allowing for greater patient care. From the above results the following conclusion can be drawn that Most of the students have a basic idea about what a laser is and its uses in dentistry but they are not aware of types of lasers and there is no significant gender variation with the awareness level of dental lasers. There is a requirement for students to gain knowledge and how to use different types of lasers by conducting practical sessions.

\section{REFERENCES}

Anbu, R. T. et al. (2019) 'Comparison of the Efficacy of Three Different Bone Regeneration Materials: An Animal Study', European journal of dentistry, 13(1), pp. 22-28.

Ariga, P. et al. (2018) 'Determination of Correlation of
Figure. 13: The above figure represents awareness on the usage of hard tissue lasers over soft tissues. blue is 'yes', Red is 'no', and green is 'may be'. Only $22.12 \%$ of the population are aware that both hard tissue lasers cannot be used in soft tissues.

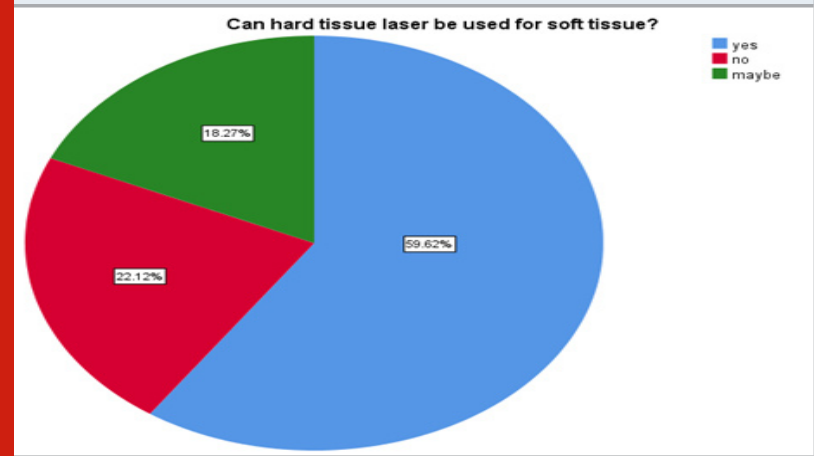

Figure 14: The above given figure represents association between gender and the usage of hard tissue lasers over soft tissues. Green is 'yes', Red is 'no', and green is 'no idea'. $\mathrm{X}$-axis represents gender and Y-axis represents the number of participants. $12.50 \%$ of the male population and $9.62 \%$ of the female population say it as no. Chi-square value $=1.188, \mathrm{P}$ value $=0.552,(>0.05)$ hence, statistically not significant. Although statistically not significant it is implied that, majority of males $12.50 \%$ are aware that hard tissue lasers cannot be used for soft tissues.

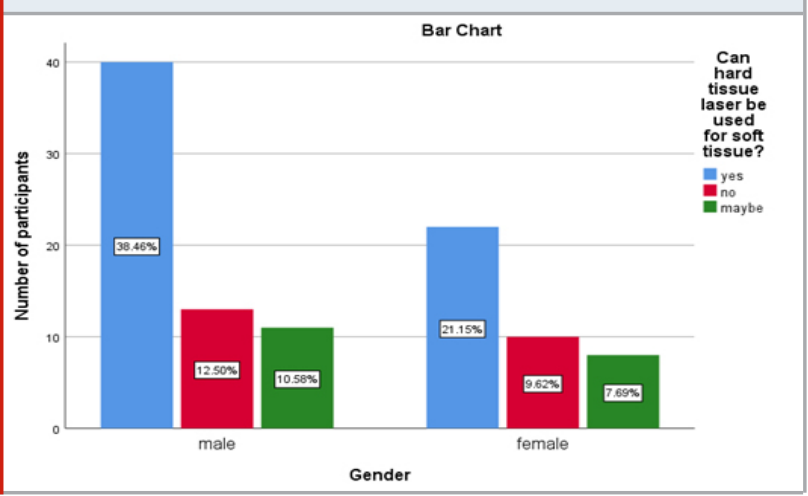

Width of Maxillary Anterior Teeth using Extraoral and Intraoral Factors in Indian Population: A Systematic Review', World Journal of Dentistry, pp. 68-75. doi: 10.5005/jp-journals-10015-1509.

Aronoff, B. L. (1982) 'Advantages And Disadvantages Of The Laser', Lasers in Medicine and Surgery. doi: 10.1117/12.976077.

Ashok, V. and Ganapathy, D. (2019) 'A geometrical method to classify face forms', Journal of Oral Biology and Craniofacial Research, pp. 232-235. doi: 10.1016/j. jobcr.2019.06.001.

Deogade, S., Gupta, P. and Ariga, P. (2018) 'Effect of monopoly-coating agent on the surface roughness of a tissue conditioner subjected to cleansing and disinfection: A Contact Profilometric In vitro study', 
Contemporary Clinical Dentistry, p. 122. doi: 10.4103/ ccd.ccd_112_18.

Dostálová, T. and Jelínková, H. (2013) 'Lasers in dentistry’, Lasers for Medical Applications, pp. 604-627. doi: 10.1533/9780857097545.4.604.

Duraisamy, R. et al. (2019) 'Compatibility of Nonoriginal Abutments With Implants', Implant Dentistry, pp. 289-295. doi: 10.1097/id.0000000000000885.

Freitas, P. M. de et al. (2015) 'Selective caries removal, cavity preparation and adhesion to irradiated tissues', Lasers in Dentistry, pp. 63-71. doi: 10.1002/9781118987742.ch10.

Ganapathy, D. M., Kannan, A. and Venugopalan, S. (2017) 'Effect of Coated Surfaces influencing Screw Loosening in Implants: A Systematic Review and Metaanalysis', World Journal of Dentistry, pp. 496-502. doi: 10.5005/jp-journals-10015-1493.

Graeber, J. J. (2006) 'Lasers in Dentistry', Yearbook of Dentistry, pp. 349-350. doi: 10.1016/s00843717(08)70278-2.

Heinrich, A. et al. (2011) 'High power, diode-pumped Er:YAG lasers for soft and hard tissue applications', Medical Laser Applications and Laser-Tissue Interactions V. doi: 10.1364/ecbo.2011.80921c.

Jablonski-Momeni, A. et al. (2019) 'Use of a laser fluorescence device for the in vitro activity assessment of incipient caries lesions', Journal of orofacial orthopedics = Fortschritte der Kieferorthopadie: Organ/official journal Deutsche Gesellschaft fur Kieferorthopadie, 80(6), pp. 327-335.

Jain, A. R. (2017a) 'Clinical and Functional Outcomes of Implant Prostheses in Fibula Free Flaps', World Journal of Dentistry, pp. 171-176. doi: 10.5005/jp-journals10015-1433.

Jain, A. R. (2017b) 'Prevalence of Partial Edentulousness and Treatment needs in Rural Population of South India', World Journal of Dentistry, pp. 213-217. doi: 10.5005/jp-journals-10015-1440.

Khalkhal, E. et al. (2020) 'Evaluation of Laser Effects on the Human Body After Laser Therapy', Journal of lasers in medical sciences, 11(1), pp. 91-97.

Mahajan, S., Srivastava, V. and Coluzzi, D. J. (2017) 'Lasers in Dentistry: Where to Begin?', Lasers in Dentistry-Current Concepts, pp. 3-15. doi: 10.1007/9783-319-51944-9_1.
Miserendino, L. and Pick, R. M. (1995) Lasers in Dentistry. Quintessence Publishing (IL).

Olivi, G. and Olivi, M. (2015) Lasers in Restorative Dentistry: A Practical Guide. Springer.

Pradhan, S. (2017) 'Lasers in Implant Dentistry', Lasers in Dentistry-Current Concepts, pp. 211-230. doi: 10.1007/978-3-319-51944-9_10.

Ramalho, K. M. et al. (2015) 'Erbium Lasers for the Prevention of Enamel and Dentin Demineralization: A Literature Review', Photomedicine and laser surgery, 33(6), pp. 301-319.

Ramos, T. M. et al. (2015) 'Effects of Er:YAG and Er,Cr:YSGG laser irradiation on the adhesion to eroded dentin', Lasers in medical science, 30(1), pp. 17-26.

Ranganathan, H., Ganapathy, D. M. and Jain, A. R. (2017) 'Cervical and Incisal Marginal Discrepancy in Ceramic Laminate Veneering Materials: A SEM Analysis', Contemporary clinical dentistry, 8(2), pp. 272-278.

Rechmann, P., Goldin, D. S. and Hennig, T. (1998) 'Er:YAG lasers in dentistry: an overview', Lasers in Dentistry IV. doi: 10.1117/12.306009.

Shih, M.-M. (2012) 'Modeling distributed feedback GaAs-based lasers in dentistry', Lasers in Dentistry XVIII. doi: 10.1117/12.912317.

Sulieman, M. (2005) 'An Overview of the Use of Lasers in General Dental Practice: 2. Laser Wavelengths, Soft and Hard Tissue Clinical Applications', Dental Update, pp. 286-296. doi: 10.12968/denu.2005.32.5.286.

Varghese, S. S., Ramesh, A. and Veeraiyan, D. N. (2019) 'Blended Module-Based Teaching in Biostatistics and Research Methodology: A Retrospective Study with Postgraduate Dental Students', Journal of Dental Education, pp. 445-450. doi: 10.21815/jde.019.054.

Vescovi, P. et al. (2010) 'Surgical approach with Er:YAG laser on osteonecrosis of the jaws (ONJ) in patients under bisphosphonate therapy (BPT)', Lasers in medical science, 25(1), pp. 101-113.

Yamamoto, H., Atsumi, K. and Kusakari, H. (1989) Lasers in Dentistry: Proceedings of the International Congress of Laser in Dentistry, Tokyo, Japan, 5-6 August 1988. Elsevier Science Limited.

Zein, R. (2017) 'Practical Application Of Lasers In Every Day Dentistry', Dentistry. doi: 10.4172/2161-1122-c1023. 